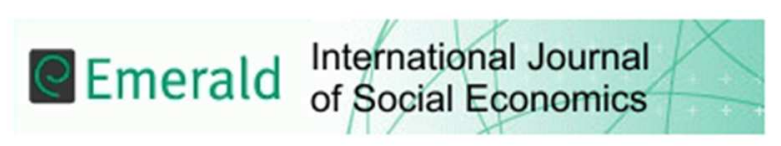

\title{
A multi-disciplinary approach to explaining workless-ness in Britain
}

\begin{tabular}{|r|l|}
\hline Journal: & International Journal of Social Economics \\
\hline Manuscript ID & IJSE-10-2015-0267.R1 \\
\hline Manuscript Type: & Research Paper \\
\hline Keywords: & Demography, Employment, Gender, Human Capabilities \\
\hline \multicolumn{2}{|l}{} \\
\hline
\end{tabular}

SCHOLARONE
Manuscripts 
A multi-disciplinary approach to explaining workless-ness in Britain

\section{Structured Abstract}

Purpose - The purpose of this paper is to adopt the principles of labour economics, behavioural economics and social influence to identify constraints and enablers that influence people's choices in relation to the labour market decisions.

Design/methodology/approach - a sequential empirical methodology has been adopted, where data from the British Household Panel Survey (2009) has been collected to explain various statuses of labour market activity, with a focus on workless-ness, across the categories of unemployment, being a student, disability, retirement and being a carer - differentiating for gender and age. The paper develops and substantiates the hypothesis theoretically and gives some indications using a multi-disciplinary approach.

Findings - we found that labour market opportunities, choices and achievements are affected by the interrelations and interactions of an individual's demographic and psychological characteristics (such as age, gender, heuristics, perceptions, beliefs, attitude's goals and ambitions) along with external factors (such as geographical, socio- cultural and economic conditions).

Originality/value - this study makes a unique contribution to labour economics as we abandon the traditional welfare approach and use a more general framework of capabilities and refined functioning to interpret how different types of constraints - ranging from socioeconomic conditions and environmental background to specific features of individual processes of choices and decision making- affect preferences and functioning's. The study also identifies how "under-employment" complements the use of BE/social influence in explaining labour market inactivity, and highlights how the findings of this study have important implications for policy.

\section{Introduction}

Over the centuries economists and social scientists have formalized different explanations to understand and predict human behaviours. The undisputed theoretical framework of mainstream economics assumes that the individuals are rational, atomized, and most importantly totally selfish, so that their behaviour is driven by pure self "interest". Our approach departs from the vision of the traditional economic actor because we take into account two important dimensions of the human race, namely the social and the personal sphere. First of all, in our model, the individual is not referred to as homo economicus but as homo "econ-amicus", meaning that in making economic decisions one is affected by social relations and by the degree of structural "embeddedness" in their surroundings - all factors that shape and constraint opportunities and independence. Secondly, in our model an individual is also referred to as homo "humanus" - that is one enters into social relations with his/her endowment of capabilities, idiosyncrasies, personality traits, human cognitive biases. .

Using Sen's (1980) capabilities approach (CA), which departs from the utilitarian approach, we aim to identity opportunities and functionings ${ }^{i}$ that are particularly relevant to labour market decisions. Sen's approach considers three factors that influence how people convert opportunities into actual achievements: personal characteristics (e.g., physical conditions, gender, skills), social characteristics (e.g., social norms, power of relations, public policies), and environmental characteristics (institutions, infrastructures). ${ }^{\text {ii }}$ In this paper we focus on the social and personal sphere.

The next section will provide brief overview of how a unified multidisciplinary approach offers a rich analysis of labour market statuses.

\section{Extending the Homo Economicus: horizontal and vertical dimensions}

Working and non-working decisions are the resultant of many interdependent forces at work. Sociality is one of those forces which interfaces with our sense of identity, affecting the emotional costs and benefits of nonemployment and employment beyond the factual monetary gains and losses.

The horizontal dimension : Homo Socialis 
Classic labour economics paper on female unemployment and labour supply in the UK follow the work of Blundell, Ham and Meghir (1987) to try to model work and unemployment and exclude those women who are defined as being inactive in the labour market. Many such studies in this traditional labour economics style are summarised in Blundell and Macurdy (1999), in most cases these papers exclude those considered to be inactive in the labour market even when focusing on females. This exclusion, whilst maybe not such an issue for men at the time, is a limitation in understanding the labour market status of women, where other options are available with regard to caring responsibilities within their families. We therefore develop a more inclusive model attempting to include both the socio-economic personalistic approach (Bowles and Gintis, 1998; Fehr and Gächter, 1998; O’Boyle, 1994, Dessi and Zhou, 2010) which identifies two dimensions of human being as well as the individualistic dimension and the social dimension.

In an empirical paper, Burchardt and Le Grand (2002) used the British Household Panel Survey (BHPS) data and Sen's (1980) CA to study voluntary and involuntary workless-ness. Among standard labour economics variables, they include some social variables, and found that after taking into account of "social"constraints, one-tenth of the non-employed sample is unambiguously voluntary. Clark (2001) used BHPS and Akerlof's (1980) approach on social comparison to test the effect of social norms on unemployment status. His findings show that the psychological cost of unemployment is less severe when unemployment is the social comparison of unemployed people, reducing the incentive creating to find work. In Clark (2006) uses Sen's capability approach to consider the importance of understanding heterogeneity between people in understanding worklessness.

Economists outside mainstream economics have tried to include social influence in labour market theories in various ways, ranging from segmented market theory (Bowles and Gintis, 1976) to human capital theory (Becker, 1976), and job search and information models (Mortenson, 2003). Empirical studies have tested the traditional labour market model alongside network analysis and in general found that: (i) personal contacts are an efficient way of finding jobs; (ii) personal contact are used less often for higher salary jobs; (iii) the presence of a wage premium for jobs found via personal contacts depends on the type of jobs and (iv) mixed evidence in job search models and the strength of ties. (Gravoetter, 1983) iii $^{\text {ii }}$

The socio-economic and social influence approaches bring useful insights into the analysis of economic choices. However empirical studies in these fields fail to include the "personal" sphere and the influence of psychological traits, feelings, fears, attitudes, on labour market decisions. ${ }^{\text {iv }}$

The vertical dimension: Homo Personalis

A large body of literature from Behavioural Economics and Psychology presents evidence about people's "inconsistent" choices. Several reasons can contribute to display a perceived "incorrect rationality". These include: i) decisions not necessarily reflecting true preferences due to constraints that have not been included in the analysis (internal factors such as emotions, perception biases, reduced cognitive abilities, or external factors such as social influence, economic and technological innovations, uncertainty); ii) preferences becoming "adapted" to unwanted/undesirable circumstances and interdependent on social relations; iii) the cognitive reference framework being used by agents to make different decisions from what economists have been assuming, especially under uncertainty, as theorized by Prospect Theory ${ }^{v}$ and iv) individual's responses to subjective well-being and hence decisions, which will vary depending on life circumstances, social comparisons, emotional states, personality traits, and memories of past experience (Kahneman and Krueger, 2006). ${ }^{\mathrm{vi}}$

We believe that labour market status and choices (particularly "inaction") that economists would consider "irrational" can be explained by referring to some Behavioural Economics (BE) principles. For instance the decision of being "inactive" (not wanting to participate to the labour market) or long term unemployment can stem from:

1. "Low self-esteem and confidence" reference point. An agent showing this behaviour has expectation of not finding a job or not being good for a job.

2. Fears expectations of precariousness of jobs. In this case, pessimism, fatalism, myopic loss aversion, heuristic representativeness and aversion for ambiguity, create an expectation that action (searching for a job) will lead only to a temporary change of status.

3. "Attitude", hedonic adaptation, social factors (conformity to norms), government benefits (economic considerations), perception of having being active, tendency for omission bias (changing status requires 
an act while keeping it requires an omission, a failure to act). In this case, the expectation is that action can lead to finding a job.

There are situations in which people can be affected by factors coming from all three categories. We identified the above typology, we created some proxy variables from the British Household Panel Survey (BHPS) and used them in our models to analyse which effect tends to dominate others.

\section{Methodology, data}

To investigate the UK labour market, we use the BHPS data for 2009, a richer multidimensional approach and a sequential two-step procedure. In the first step we use a logistic model and we differentiate between gender and we focus on modelling a binary choice between employment versus non-employment. We use the insights gained in this first step to build a second model, a Multinomial Probit, which focuses on non-employment only. This sequential model is used in order to take into account the selection process into attachment into the labour market. In addition the second stage of looking within the non-employment group, which is very heterogeneous in nature, we follow Furlong (2006) in considering smaller groups of non-employment in the second stage, although we acknowledge that even within these groups significant heterogeneity can be seen.

The BHPS provides broad and detailed information on personal characteristics and social factors. Some of the variables we used in our models were directly extracted from the survey's replies, while some others were derived variables created by combining replies to several questions or created as interaction terms.

In line with the $\mathrm{CA}$, we propose to explain labour markets statuses and choices by looking at three main conversion factors, namely: personal characteristics, psychological factors and social factors. The first set of factors are grouped under the umbrella of "labour market variables" (LMV). These are human capital factors that are typically included into standard labour marker models such as: age, education, parents' employment and non-employment status, physical condition, marital status, etc. The second set of conversion factors includes variables that capture BE principles (such as preference for status quo, loss aversion), variables that reflect personal beliefs and values, and variables that are related to psychological traits and subjective perception of well-being. The third set refers to the respondents' social characteristics, social capital and strength of embeddedness and social relations. Social norms and "close ties" represent vital additional elements of the analysis. Social influence is mediated by personal filters such as degree of job ambitions. These filters can reinforce or weaken the social influence of friends or of the environment and we account for these interrelations by using some interaction terms that reinforce or reduce the original direct effects of social norms, an all is contributing to shape agent's decisions. The complete list of variables and their explanation is reported in Appendix $1^{\text {vii }}$.

\section{A first step: employment versus non-employment.}

We use the Logistic Model for Male and Female to estimate the probability of being non-employed, controlling sequentially for various constraints and/or opportunities. This first model is auxiliary to the second and it should help identity salient differences in constraints and enablers, particularly those pertinent to social and personal dimensions and those that are gender related, that could be insightful and useful for the study workless-ness, which is at the core of this paper.

The logistic equation is applied separately to male and female to estimate the odds of being employed relative to being employed controlling for sets of variables by sequentially adding new sets of variables to the traditional labour market variables. Because the focus is ultimately on workless-ness, we omit a detailed description of the logistic model and discuss only some main findings which have been useful for modelling of non-employment. Full results of the logistic model are reported in Table 2A in Appendix 2 and discussed in Cagliesi, Hawkes and Tookey (2015).

Table 1 points out some of the gains of a multidisciplinary over the standard approach. As we move from a standard model and add more dimensions (behavioural, subjective well-being, social influence) we gain in accuracy and obtain average estimated probabilities for men and female virtually identical to the corresponding sample means. This gain in overall averages confirmed also at individual level and more individuals are correctly predicted their own status. Given our focus on non-employment, we compare each individual's personal risk of being non-employed with his/her own actual labour market status. When we account for more constraints, such as personal idiosyncracies, subjective values, and social influence, we found that more of the people with predicted risk of non-employment higher than the average are actually non-employed; similarly 
more of the people with lower than average risk of non-employment .This gain in accuracy in aligning status and prediction, helps identify better the mis-aligned cases of those who are employed despite a high personal risk of non-employment (ie., the employed against the odds) and those who are non-employed despite a low personal risk of employment (ie., the voluntary non employed).

One can notice that there is an evident consistent gender difference across all 4 models: being employed against the odds is more a male than a female characteristic as if man could compensate better than women for those characteristics that would put them at a higher risk of non-employment. Several reasons can explain this gender difference. For instance female's constraints, such as maternity for example, are more binding (less "compensable") than male's constraints. The affordability of childcare would render the less employable female less incline to accept underemployment and to prefer the status of stay at home mothers instead so as to receive benefits and look after children. Moreover recessions (the data is taken from that period) tend to hit female more than man.

The gender bias is confirmed also among those respondents who are employable (low probability of nonemployment) but who are non-employed and women are markedly more likely than man to fall in this category. This gender bias could depend on female genuine preference and choices about voluntary non-employment (ie., gender role, stay-at-home mothers and carers), or it could depend on lack of opportunities for women who would like to go back into working after the maternity break but find it difficult to resume career. This misalignment between employability and workless-ness captures some types of female underemployment such as seeking a job but not being immediately available for work and being available for work but not seeking it. The above findings highlight the importance of taking into proper account the heterogeneity of the joblessness status and they will be helpful in estimating the Probit model.

$<$ insert Table 1 here $>$

The logistic estimates highlight other important information. For both genders, age (being younger or older), limiting health condition, education, having a working partner, personality features (extroversion, conscientiousness, confidence autonomy), personal values and attitudes, and social influence (being exposed to a non-working environment and having close ties with non-employed friends) are all important factors that affect the odds of non-employment. We believe that they can also have differential effect across joblessness statuses and we will include them in the next phase of our study.

\section{A second step: workless-ness statuses across gender and age}

In view of our previous results, we use a multinomial Probit model that accounts for several categories of nonemployment according to different degrees of attachment to the labour market (unemployment, students, disabled, early retired and non-working carers), and that differentiates not only for gender but also for age categories (young 16-24; mature 25-49; old 50-64). The reference category is unemployment because it is the more attached to the labour market. The Multinomial Probit model has the following form:

where:

1) $\operatorname{Prob}(j=1)=G(L M V, B E V, S a t V, S N V, I N T E R V)$

$\operatorname{Prob}(j=1)$ is the probability of a non-employed individual to fall into one of the workless categories $(\mathrm{j}=$ retired, unemployed, student, disabled and non-working carer)

$G$ (..) is the cumulative distribution function when assuming that the stochastic error term is $\operatorname{IN}\left(0, \sigma^{2}\right)$

$L M V$ is a set of labour market variables

$B E V$ is a set of behavioural variables

$\mathrm{Sat} V$ is a set of subjective well-being variables

$S N V$ is a set of social relations and social influence variables

INTERV is a set of interaction variables

The estimated coefficients of the multinomial Probit models are reported in Appendix 2 (Tables 2B, 2C and 2D). By looking at the signs of the coefficients, it is possible to identify some clear differences between genders and across different age groups, some of which are expected because age and group membership are strongly related. Social influence affects both genders in a way that confirms the logit model's results: women are affected by the status of inactive friends (a groups less attached to the labour market) and by embedded-ness in the environment while men are influenced by active friends (a category more attached to the labour market). 
To gain information on the order of magnitude of the effects of each variable on the relevant probabilities we would need to look at the marginal effects reported in Tables 2 and 3. Wanting to change status is among the most important variables, particularly when it comes to young and mature males, who seem to "suffer" more than older males and females from being unemployed. Constraints such as having limiting disability or young children, having no qualification or low level of education, exert also strong effects together with social influence, individuals' preferences and attitudes.

$<$ insert Table 2 here $>$

$<$ insert Table 3 here $>$

The marginal effects of each variable in each age group are computed by taking the rest of the covariates at their respective (age group) average values. However, different people in the same age group may present values of covariates that are much higher or lower than the age group mean. Thus, for each age group (and gender) we computed the estimated probabilities of some non-employment statuses after controlling for the specific values of covariates instead of taking them at their mean values. Tables $4-6$ report these calculations.

\subsection{Non-working young people (16-/24 years old): the female students and the unemployed male.}

From Table 4.A, one can see that a young non-working female has a high estimated probability (55\%) of being a student. However, this probability changes when we account for the effects of specific her individual characteristics. So for instance this probability increases to $97 \%$ for a "young" female with no caring constraints (no young children), who is happy to keep her status quo, who has strong ties with non-working friends, is happy to conform to this social rule, and is rather conscientious (above average). Conscientiousness in this case, when associated with some specific individual's characteristics tends to increase the probability of being a student relative to all other categories (despite the negative sign in the "average" estimates).

$<$ Insert Table 4.A here $>$

$<$ Insert Table 4.B here $>$

A young non- working male has a $28 \%$ chance to be unemployed and a $72 \%$ probability to be inactive. However, as shown in Table 4.B, when controlling for specific and individual values of factors (rather than for average values) this probability can vary substantially, ranging from a low of $4 \%$ to a high of $94 \%$. The low probability is related to the case of a young male who has educational qualifications and is inclined to preserve rather than change his non-working status quo (a situation which is more "attuned" with the characteristics of a student). Indeed, being inactive, differently from being unemployed, is a matter of personal choice and often of enablers (such as education). This is confirmed by the fact that the highest probability of being unemployed is that one of a young man, who does not have any educational qualification, is surrounded by non-working friends and would like to change his status valuing a fulfilling job as being to some extent important. This young male could represent that part of the Non in Education, Employment and Training young people (NEET) who are less detached from the labour market.

The lack of education is clearly a significant constraint, but personal attitude and values can be significant constraints or enablers. For instance a young man who is again "educationally constrained" but who does not want to change his status, faces a probability of being unemployed much lower $(20 \%)$ than the average (28\%) and certainly much lower than $94 \%$. This lower than average figure suggests that such a young male is quite likely to be among the "detached "NEET, who are economically inactive and hence not seeking work and/or not available to start work.

The findings indicate that education constraints plays a different role depending on the willingness to change status. Indeed the most likely unemployed young male is that young male who does not want to be workless, does not want a life of benefits, who is surrounded by similar non-working friends and who believes that having a fulfilling and gratifying job is somehow important. Active labour market policies that create incentive such as promoting apprenticeship and training may help better than punitive policies of cutting benefit because they can empower these "more attached" NEET to move into a fulfilling job.

The case of a young non-qualified male with $94 \%$ probability of unemployment is an interesting situation, because, despite the fact that valuing a good job can mitigate the social influence of non-working friends and hence it can reduce the average probability of being unemployed (the variable DeviateNW has a negative marginal effect), the situation can change and revert when we take into account other specific personal features 
such as lack of qualification and moderate value for working. This contrasting effect of factors at the average versus individual level can be seen also in the case of the young female student and the factor conscientious identified above. This means that when we move from mean values of the covariates into individual characteristics, the combination and the absence/presence of values of these specific characteristics can produce predictions that can differ from those obtained when using mean values. Individual idiosyncrasies affect the impacts of factors.

\subsection{Mature (25- 49 years old) non-working people: carers and disabled males}

Table 5.A reports that non-working women in this age group have a high chance ( $62 \%$ estimated average probability) of being at home carers. This probability increases to $85 \%$ for those women with young children who place very high values to family life and who do not want to change their non-working status. This result is not surprising. However, it is interesting to notice that the probability of being an "at home carer" increases quite substantially (up to 77\%) for those women who also have young children and place high value to family life, but who instead of keeping it, want to change their status quo. This category may represent the case of mature women who may have left the job market to choose temporarily a non-working status but who want to resume full or part time work.

$<$ Insert Table 5.A here $>$

For mature non- working men, the average probability of belonging to the disabled category is $44 \%$, while the average probability of being unemployed di $52 \%$. The $44 \%$ increases substantially up to $96 \%$ when we consider those non-working men declaring to have limiting disabilities, and some other personal characteristics such as: not wanting to change the labour market status, having a low level of relatedness (lower than 3 on a scale from 1 to 5), and not placing much value (lower than 13 on a scale from 2 to 20) on wealth. This high probability is expected. What is less expected is that those mature men who also have low level of relatedness, low value to wealth and limiting disability but who declare instead that they want to change the non-working status (possibly into full or part time job) rather than keeping it, have a $75 \%$ probability of belonging to the disabled category. This is a high figure, well above the $44 \%$ average which may capture one of the feature of mature male workless-ness status: the tendency, while waiting to find a job, to prefer declaring some disabilities and receiving disability benefits rather than to declare unemployment.

$<$ Insert Table 5.B here $>$

4.3Old (50 - 65 years old) non-working people: early retired males

For this age group qualification and social influence are factors that play a crucial role in refining more accurately the probability of early retirement. For instance, while the average of the group is $50 \%$, the probability of retirement jumps to $97 \%$ when we consider an old able male (with no limiting disabilities), who has some qualifications (or some level of education) and with all inactive friends. On the other hand, old able people with no qualification and with all active friends, are much more likely to be unemployed than to be retired. Thus old males choosing early retirement are most likely to be those possessing some level of qualification and education which offered them better chances to have well paid jobs and, hence, to afford either to retire at an earlier stage, or to not work and to wait to return to full or part time employment without transiting through unemployment. These people tend to associate themselves and being strongly affected by similarlyminded friends

$<$ Insert Table 6 here $>$

Our results indicate that the use of a cross disciplinary approach of labour economics, behavioural economics and social network analysis can generate significant benefits in terms of policy making and policy prescriptions, because it provides useful insights into inaction that can better orientate the design of effective labour market policies.

\section{The influence of "under-employment" on inactivity in the labour market}

Underemployment has been defined in various ways. According to ONS and LFS definition underemployment is unemployment plus those who are working part-time and working fewer hours than wished. The ILO definition is broader and it includes those not searching for work but who would be ready for work and those 
searching for job but not ready for it as all these are not considered unemployed but inactive. In terms of this study we have largely used the latter as the definition of under-employment.

The term "under-employment" generally refers to an employment situation where there is a disparity between the qualifications and skills that an employee possesses and the work they carry out (Feldman, 1996). Examples would include holding a part-time job despite desiring full time work, or where an employee has a level of education, skills and experience that is far beyond the requirements of a job - such as a Master's graduate working as a Barista in Starbucks.

While under-employment has yet to enter the domain of research in BE and social influence, one cannot ignore the effect that it is having on the present job climate in the UK. For example, recent data from the Office for National Statistics (ONS) said there had been an upward trend in the proportion of recent graduates working in non-graduate jobs - up from 37 per cent in 2001 to 47 per cent by 2013, with most with most of the increase happening since the 2008/09 recession.

So while this study found that BE and social capital play a large role in explaining inactivity in the labour market (taking account of differences between genders, types of inaction and age groups), the influence of under-employment in accounting for labour market inactivity should also be taken into consideration. However, to understand the influence that under-employment might have on labour market inactivity, the distinction between objective and subjective perspectives should be taken into account (Khan \& Morrow, 1991). While objective measures of this perspective tend to predominate, it should also be recognised that there exist contextual and interpretive frameworks that individuals draw upon to make sense of their present economic situation (Feldman, 1996; Johnston, 2003), and this finding could be applied to the present study. For example, the estimated nested mean model that used to predict the probabilities of being non employed recognised a discrepancy between an individual's employment status and their types of employment probabilities, and it was found that one of the factors in explaining this discrepancy was personal choice and efforts - again reflecting how contextual and interpretive frameworks may be used to make sense of one's present economic situation. So while inactivity in the labour market can be explained by BE principles, it is interesting to observe that the causality of labour market inactivity shares similarities with the phenomenon of under-employment.

The principles of BE and social influence which were utilised in this study showed some interesting differences in labour market inactivity (across a variety of different demographic variables). In view of this, the significance of research on under-employment (and the influence of the "subjective" aspects of these phenomenon) could complement the use of BE and social influence in explaining labour market inactivity and open a "black box" for revealing what challenges lay ahead in future research in this area.

\section{Policy evaluation, conclusion, and limitation}

In this empirical study have used a new cross-disciplinary approach among labour economics, behavioural economics (BE) and social economics to explain agents' decisions over labour market statuses. Based on the framework of capabilities and refined functioning proposed by Amartya Sen (1980) we develop and test a model of non-employment that is much broader than those usually estimated within labour economics. We find, in addition to standard labour economic variables, $\mathrm{BE}$ and social economics are potentially important in explaining non employment. In addition there are important differences found between the genders, across the different types of inaction and between age groups.

Whilst the analysis presented above should be viewed within the context of some potentially important limitations. Firstly all of the measures used are not collected directly for the purpose but are derived variables constructed from data collected from a large household survey. This means that the data may not measuring BE biases or does not capture psychological effects. In addition the measures of social influence are very much proxies rather than true measures of embedded-ness. However, the results they present suggest that the collection of such data would be worthwhile, and is indeed the next stage of this project. Secondly the results clearly need to be considered within the content of the potential of endogeneity coming from social network variables (Mansky, 1993) and from preference variables. Therefore it is wise to think of this study as providing useful insights into additional factors from $\mathrm{BE}$ and social influence that may be associated with workless-ness.

Our results suggest that some labour market choices and statuses that economists would consider "irrational" can be explained by referring to some Behavioural Economics (BE) principles, to personal motivation and to social influence. We stress here that the policies play a big role in affecting people's ability to change these choices because, differently from personal traits, some factors such as loss aversion and the status quo bias are 
not fixed innate characteristics, and hence, as such they could be influenced by the correct policy and nudges. How can policies achieve this? By creating changes in pressures (internal or external) that would prompt an individual to make an effort to leave his "inert" area (which is the habitual range of effort levels set by the individual and/ or by group norms). Therefore the change in (internal or external) pressure created by the policy ought to be sufficient enough to make the costs of remaining in the area exceed the benefit. Well designed, well framed and well informed government policies can affect an individual's reference point, his level of social conformity, and motivate to action.

Two main lessons can be drawn from the multidisciplinary approach proposed in this study. Firstly, when we consider different type of individuals' constraints and predispositions, degrees of social influences, and the most common traits of human race (fear of losses), economic agents display a behaviour that can be seen as being economically irrational or "bounded" rational or irrational - but it is for sure more "human" and hence "credible" than the mechanic, mathematically predictable homo-economicus. Secondly these results suggest that the proposed redesign of the benefit system and additional support for those not currently employed needs to allow for a degree of heterogeneity in the client basis. A handful of policies, such as the New Deal and the Tax Credits system, have been designed with this heterogeneity in mind by age and type of inactively. The results above suggest that a consideration of factors wider than the standard labour economic variable when designing labour market policies may provide fruitful returns.

In a paper on labour market inactivity and attachment in Britain, Little (2007) established that a substantial degree of behavioural heterogeneity existed in the behaviour of economically inactive individuals, with the social security system playing a large role in influencing the timing and probability of moving towards different labour market states. In view of this, future research could focus on how BE principles may play a role in explaining the working culture of social security systems in the UK, and how this influences patterns of labour market activity.

At a time of large anticipated change in the welfare system, with a move to the Universal Credit and increased use of private providers in the provision of Work Programme courses to encourage the unemployed back to work, it is important that these policy reforms take account not just of the active labour market statuses of employed and unemployed, but also take account of the traditional inactive states such as disability, early retirement and motherhood. It is also important that when considering policies around making work pay more than the standard labour economics variables are considered. Policy design will only be effective where it is also designed mindful of both the individualistic dimension and the social dimension as possible nudges for encouraging the workless to engage with the labour market. 


\section{References}

Akerlof, G. (1980). A Theory of Social Custom, of Which Unemployment may be One Consequence. The Quarterly Journal of Economics, 94 (4), 749-775.

Becker, G. (1976). The Economic Approach to Human Behaviour, Chicago: University of Chicago Press.

Blundell, R. and Macurdy, T. (1999) Labor Supply: A Review of Alternative Approaches, Chapter 27, Handbook of Labor Economics, 3 (A), 1559-1695

Blundell, R., Ham, J., and Meghir, C. (1987). Unemployment and Female Labour Supply. The Economic Journal, 97, Conference Papers 1987, pp44-64

Bowles, S. \& Gintis, H. (1976). Schooling in Capitalist America. New York: Basic Books.

Bowles, S. \& Gintis, H. (1998). Is equality Passé? Homo Reciprocans and the future of Egalitarian Politics. Boston Review, December.

Burchardt, T. \& Le Grand, J. (2002). Constraint and opportunity: identifying voluntary non-employment. Centre for Analysis of Social Exclusion Working Paper Series, paper 55.

Cagliesi, G., Hawkes, D. \& Tookey, M. (2015). A Multidisciplinary approach to workless-ness: a matter of opportunities, social factors and individual's idiosyncracies. DoQSS Working Paper 15-01. Department of Quantitative Social Science - UCL Institute of Education, University college, London.

Cappellari L, \& Tatsiramos K. (2010). Friends' Network and Job Finding Rates. IZA Discussion Paper N. 5240

Clark, A. (2001). Unemployment as a Social Norm: Psychological Evidence form Panel Data. DELTA Working Papers , 2001-17.

Clark, D.A. (2006). The Capability Approach: Its development, Critiques and Recent Advances. Global Poverty Research Group Working Paper Series, GPRG-WPS-032.

Dessi’ R. \& Zhao X. (2010). Self Esteem, Shame and Personal motivation. IDEI Working Papers 639.

Fehr, E \& Gächter, S. (1998). Reciprocity and Economics: The Economic Implications of Homo Reciprocans. European Economic Review, 42, 845-859

Feldman, D. C. (1996). The nature, antecedents and consequences of underemployment. Journal of Management, 22(3), 385-407

Furlong, A. (2006). Not a very NEET solution: representing problematic labour market transitions among early school-leavers. Work, Employment and Society, Volume 20 (3), 552-569

Goyal, S. (2007). Connections: An Introduction to the Economics of Networks. Princeton, NJ: Princeton University Press.

Granovetter, M.S. (1985): Economic Action and Social Structure: The Problem of Embedded-ness. American Journal of Sociology, 91 (3), 481-510.

Jones-Johnson, G. \& Johnson, W.R. (1991). Subjective under-employment and psychosocial stress: the role of perceived social and supervisor support”, The Journal of Social Psychology, Vol. 132 No. 1, pp. 11-21.

Kalish Y. \& Robins G. (2006) Psychological Predispositions and Network Structures: The Relationship between Individual Predispositions, Structural Holes and Network Closure. Social Networks, 28 (1), 56-84.

Kahneman, D. \& Krueger A. (2006). Developments in the Measurement of Subjective Well Being. Journal of Economic Perspectives, 20 (1), 3-24. 
Khan, L.J.\& Morrow, P.C. (1991). Objective and subjective under-employment relationships to job satisfaction. Journal of Business Research, Vol. 22, pp. 211-18.

Little, A. (2007). Inactivity and labour market attachment in Britain. Scottish Journal of Political Economy 54 (10) pp19-54.

Mansky, C.F. (1993). Identification of Endogenous Social Effects: The Reflection Problem. Review of Economic Studies, 60, 531-542.

Mortenson, D. (2003). Wage Dispersion: Why are Similar Workers Paid Differently? Cambridge, MA: MIT Press.

O’Boyle, E. (1994). Homo socio-economicus: Foundational to Social Economics and the Social Economy. Review of Social Economy, 52, 286-312.

Sen, A. (1980). Equality of What? In A. Sen (Ed.), Choice ,Welfare and Measurement, Oxford: Blackwell, 353 369.

Sen, A. (2002). Response to commentaries. Studies in international Comparative International Development, 37 (2), 78-80.

Tversky, A. \& Kahneman, D. (2000). Choices, Values, and Frames. Cambridge, MA: Cambridge University Press.

\section{Endnotes}

${ }^{1}$ The CA focuses on what people are effectively able to do and to be (capabilities). Sen (2002) defines capabilities as opportunities, advantages or freedom and functionings as achievements.

${ }^{2}$ Due to the endogeneity of social effects (interdependence of preferences) empirical studies of social interactions are challenged by the reflection problem pointed out by Mansky (1993) that reduces the possibility of drawing correct inference from the data. In a recent empirical study, Cappellari and Tatsiramos (2010) took this aspect into account and estimate the effect of social network on job finding rates by using a direct measure of social interactions.

${ }^{3}$ For a review on the theoretical ad empirical works about the role of social networks in the labour market see Goyal (2007).

${ }^{4}$ For a review on Prospect Theory see Tversky and Kahneman (2000)

${ }^{5}$ Psychological predispositions influence sociality. Extraverted types have larger groups with more diverse elements, and tend not to be inclusive and not to keep their close network partners separate. On the other hand individualist types, with high level of neuroticism tend to have smaller networks with more weak ties, and tend to keep their close network partners separate. (Kalish and Robins, 2005)

${ }^{6}$ It is worth mentioning that the explanatory variables included in the Logistic and Multinomial Probit models, with the exclusion of the interaction terms, have been checked for the cross-correlation. Overall with the exception of "the reservation wage" and "wanting to change from non-employment into working", the correlations are not very high and not important in both models for all groups of working and jobless individuals. This fact suggests the correlations are driven by the differences between groups rather than explaining difference within the groups 


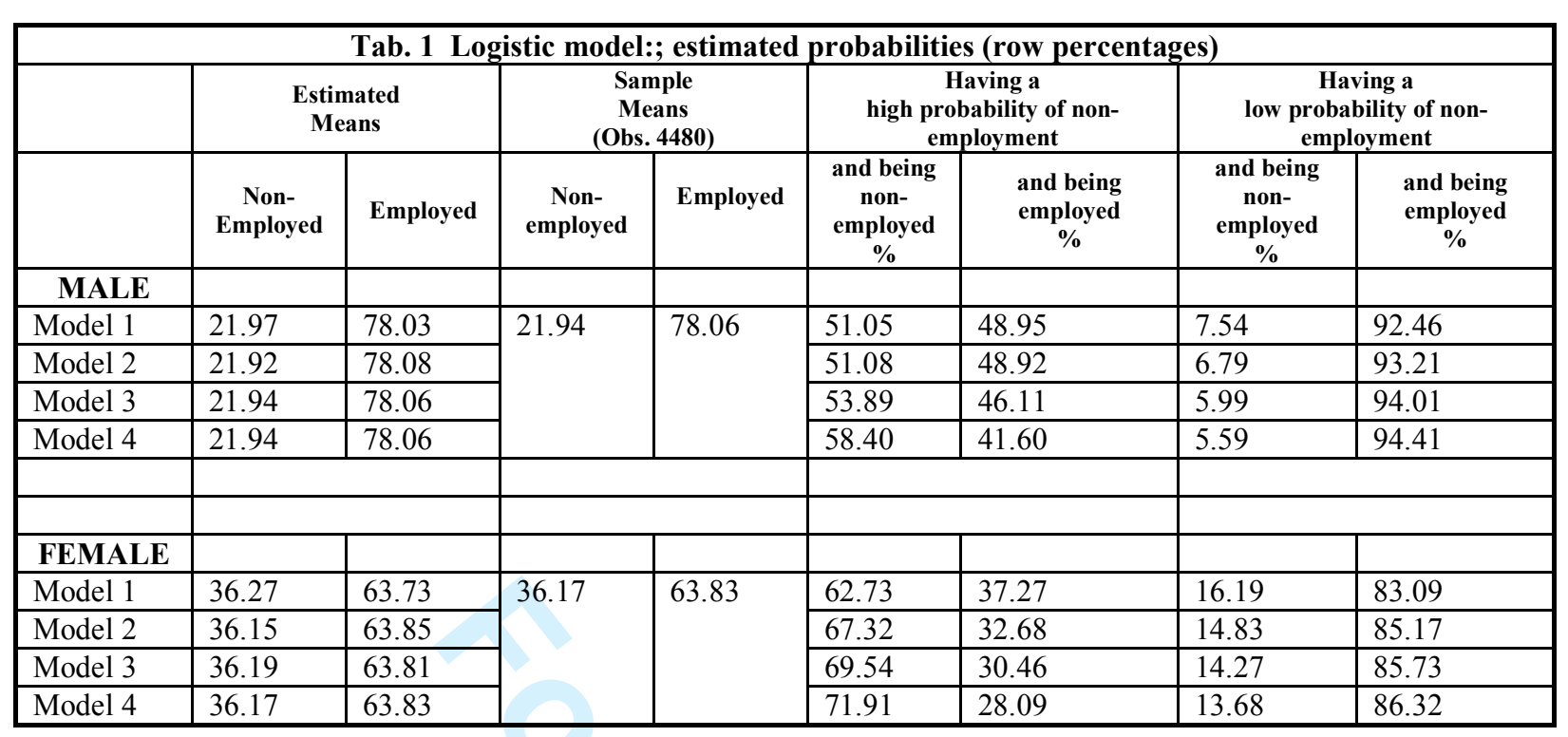




\begin{tabular}{|c|c|c|c|c|c|c|}
\hline & \multicolumn{2}{|c|}{ Young 16-24 (Obs. 272) } & \multicolumn{2}{|c|}{ Mature 25-49 (Obs. 225) } & \multicolumn{2}{|c|}{ Old 50-64 (Obs. 291) } \\
\hline & \multicolumn{6}{|c|}{ Change in probability of being } \\
\hline & $\begin{array}{l}\text { Student } \\
\text { (Obs. 183) }\end{array}$ & $\begin{array}{l}\text { Unemployed } \\
\text { (Obs. 77) }\end{array}$ & $\begin{array}{l}\text { Disabled } \\
\text { (Obs. 98) }\end{array}$ & $\begin{array}{l}\text { Unemployed } \\
\text { (Obs. 117) }\end{array}$ & $\begin{array}{l}\text { Disabled } \\
\text { (Obs. 107) }\end{array}$ & $\begin{array}{l}\text { Retired } \\
\text { (Obs. 146) }\end{array}$ \\
\hline Black or ethnic minority & & & & & $\begin{array}{c}0.39 \\
(2.59)\end{array}$ & $\begin{array}{c}-0.44 \\
(-2.73)\end{array}$ \\
\hline Edu: no qualification & $\begin{array}{c}-0.18 \\
(-2.71)\end{array}$ & $\begin{array}{c}0.21 \\
(3.53)\end{array}$ & & & $\begin{array}{c}0.12 \\
(2.75)\end{array}$ & $\begin{array}{c}-0.16 \\
(-3.93)\end{array}$ \\
\hline Edu: GCSE level & & & & & $\begin{array}{c}0.10 \\
(1.65)^{*}\end{array}$ & $\begin{array}{c}-0.14 \\
(-2.59)\end{array}$ \\
\hline Responsibilities of caring & & & $\begin{array}{c}-0.10 \\
(-2.00) \\
\end{array}$ & $\begin{array}{c}0.12 \\
(2.47) \\
\end{array}$ & & \\
\hline $\begin{array}{l}\text { Limiting health } \\
\text { conditions }\end{array}$ & & & $\begin{array}{c}0.32 \\
(8.29)\end{array}$ & $\begin{array}{l}-0.31 \\
(-7.37)\end{array}$ & $\begin{array}{c}0.26 \\
(7.07)\end{array}$ & $\begin{array}{c}-0.11 \\
(-2.72)\end{array}$ \\
\hline Doing voluntary work & $\begin{array}{c}0.16 \\
(3.30)\end{array}$ & $\begin{array}{c}-0.17 \\
(-3.87)\end{array}$ & & & & \\
\hline Loss in optimism & & & & & & $\begin{array}{c}-0.04 \\
(-2.93)\end{array}$ \\
\hline Relatedness & & & $\begin{array}{c}-0.08 \\
(-3.11)\end{array}$ & $\begin{array}{c}0.05 \\
(1.83)^{*}\end{array}$ & & \\
\hline Conscientiousness & & $-0.01(-1.96)$ & & & & \\
\hline Value of job & & $0.03(2.35)$ & $\begin{array}{c}-0.02 \\
(-1.71)^{*}\end{array}$ & & & \\
\hline Value of wealth & & & $\begin{array}{c}-0.01 \\
(1.64)^{*}\end{array}$ & $\begin{array}{c}0.02 \\
(2.92)\end{array}$ & & \\
\hline $\begin{array}{l}\text { More satisfied than in the } \\
\text { past }\end{array}$ & & $\begin{array}{c}-0.09 \\
(-1.82)^{*}\end{array}$ & & $\begin{array}{c}-0.14 \\
(-2.03)\end{array}$ & & \\
\hline $\begin{array}{l}\text { Less satisfied than in the } \\
\text { past }\end{array}$ & $\begin{array}{l}-0.15 \\
-2.64)\end{array}$ & $\begin{array}{c}0.10 \\
(1.90)^{*}\end{array}$ & & & & \\
\hline Satisfied with family life & & & & & $\begin{array}{c}-0.02 \\
(-3.32) \\
\end{array}$ & $\begin{array}{c}0.02 \\
(4.81) \\
\end{array}$ \\
\hline $\begin{array}{l}\text { Want to change } \\
\text { labour market status }\end{array}$ & $\begin{array}{c}-0.32 \\
(-7.87)\end{array}$ & $\begin{array}{c}0.35 \\
(9.21)\end{array}$ & $\begin{array}{c}-0.23 \\
(-5.19)\end{array}$ & $\begin{array}{c}0.30 \\
(7.01)\end{array}$ & & $\begin{array}{c}-0.18 \\
(-4.08)\end{array}$ \\
\hline $\begin{array}{l}\text { Capabilities and material } \\
\text { opportunities }\end{array}$ & & & & & $\begin{array}{c}-0.03 \\
(-2.13)\end{array}$ & $\begin{array}{c}0.05 \\
(4.17)\end{array}$ \\
\hline More embedded & & $\begin{array}{c}-0.07 \\
(-1.68)^{*}\end{array}$ & & & & \\
\hline Strength of social ties & & & & & & $\begin{array}{c}-0.14 \\
(-2.55)\end{array}$ \\
\hline InterINACTtie & & & $\begin{array}{l}-0.25 \\
(-1.97)\end{array}$ & & & \\
\hline InterACTtie & $\begin{array}{c}-0.17 \\
(-2.43)\end{array}$ & $\begin{array}{c}0.16 \\
(2.56)\end{array}$ & & & & \\
\hline $\begin{array}{l}\text { High local unemployment } \\
(>30 \%)\end{array}$ & & & & & & $\begin{array}{c}-0.22 \\
(-2.20) \\
\end{array}$ \\
\hline $\begin{array}{l}\text { Proportion of inactive } \\
\text { friends }\end{array}$ & & & & & & $\begin{array}{c}0.19 \\
(3.28)\end{array}$ \\
\hline DeviateNW & $\begin{array}{c}0.17 \\
(2.85)\end{array}$ & $\begin{array}{c}-0.12 \\
(-2.24)\end{array}$ & & & $\begin{array}{l}-0.10 \\
(-2.14)\end{array}$ & \\
\hline
\end{tabular}


Table 3. Marginal effect for Females (computed at average values; $Z$ values in parenthesis) Note: the asterisk * indicates a $10 \%$ level of significance

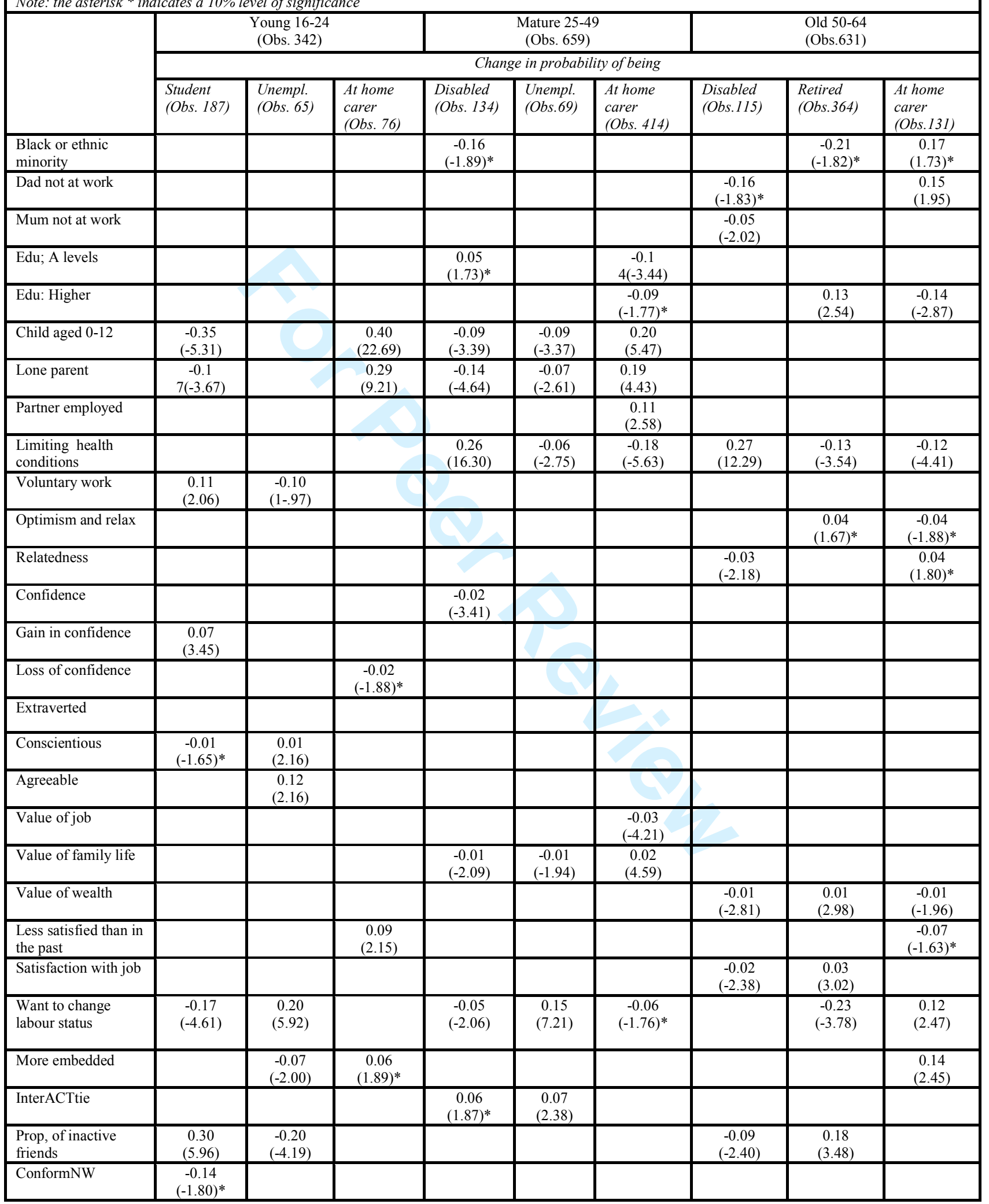


Table 4.A Estimated probabilities after controlling for "individual" factors: Young Female (age 16-24)

Average group probability of being student $=55 \%$

Estimated individual probability of being unemployed for a young female who:

\begin{tabular}{|c|c|c|c|c|c|}
\hline & \multirow{2}{*}{$\begin{array}{l}\text { Has all } \\
\text { active } \\
\text { friends }\end{array}$} & \multicolumn{4}{|c|}{ Has all inactive friends, } \\
\hline & & & $\begin{array}{lr}\text { And a different } \\
\text { degree } & \text { of } \\
\text { conscientiousness }\end{array}$ & $\begin{array}{l}\text { A degree of } \\
\text { conscientiousness } \\
\text { below average, and } \\
\text { who may either } \\
\text { conform or not } \\
\text { conform with the } \\
\text { non-working rule of } \\
\text { her closest friends. }\end{array}$ & $\begin{array}{l}\text { And a degree of } \\
\text { conscientiousness above } \\
\text { the average, and who may } \\
\text { either conform or not } \\
\text { conform with the non- } \\
\text { working rule of her closest } \\
\text { friends }\end{array}$ \\
\hline $\begin{array}{l}\text { Has no young } \\
\text { children and } \\
\text { wants change } \\
\text { Status }\end{array}$ & $28 \%$ & $78 \%$ & $\begin{array}{l}63 \% \text { (above average) } \\
81 \% \text { (below average) }\end{array}$ & $\begin{array}{l}72 \%(\text { conform })\left(^{\wedge}\right) \\
84 \%(\text { not conform) }\end{array}$ & no effect \\
\hline $\begin{array}{l}\text { Has no young } \\
\text { children and } \\
\text { does not want } \\
\text { to change } \\
\text { status }\end{array}$ & $50 \%$ & $92 \%$ & $\begin{array}{l}91 \% \text { (above average ) } \\
93 \% \text { (below average) }\end{array}$ & $\begin{array}{l}83 \% \text { (conform) } \\
94 \% \text { (not conform) }\end{array}$ & $\begin{array}{l}97 \% \text { (conform) } \\
90 \% \text { (not conform) }\end{array}$ \\
\hline \multicolumn{6}{|c|}{$\begin{array}{l}\text { Values of Conscientiousness above } 17 \text { are higher than the average of the young female group which is } 15 \text { ina range } \\
\text { between the range of } 0 \text { to } 30 \text {; } \\
(\wedge) \text { To conform is when the dummy variable Conform NW is equal to one which is the case when someone , who } \\
\text { has some or all non-working friends, is not job ambitious and believes that it is not important to have a fulfilling } \\
\text { and gratifying job. }\end{array}$} \\
\hline
\end{tabular}


Table 4.B Estimated probabilities after controlling for "individual" factors: Young Male (age 16-24) Average group probability of being unemployed $=28 \%$

Estimated individual probability of being unemployed for a young male who:

\begin{tabular}{|c|c|c|c|c|c|}
\hline & \multirow{2}{*}{$\begin{array}{l}\text { Does not } \\
\text { want to } \\
\text { change } \\
\text { status }\end{array}$} & \multicolumn{4}{|c|}{ Wants to change status } \\
\hline & & & $\begin{array}{lr}\text { And has tie with } \\
\text { active } & \text { friends } \\
\text { (employed } & \text { or } \\
\text { unemployed): } & \end{array}$ & $\begin{array}{lr}\text { And has strong ties } \\
\text { with active } & \text { friends } \\
\text { (employed } & \text { or } \\
\text { unemployed) } & \text { and } \\
\text { values job: } & \end{array}$ & $\begin{array}{l}\text { has strong ties with } \\
\text { unemployed friends, } \\
\text { values job below or above } \\
\text { average and has preference } \\
\text { that may either deviate or } \\
\text { not deviate from his } \\
\text { friends' non-working norm }\end{array}$ \\
\hline $\begin{array}{ll}\text { Has } & \text { no } \\
\text { qualifications }\end{array}$ & $20 \%$ & $81 \%$ & $\begin{array}{l}66 \% \text { (no strong } \\
\text { ties) } \\
89 \% \text { (strong ties) }\end{array}$ & $\begin{array}{l}93 \% \text { (below the group } \\
\text { average) } \\
87 \% \text { (above the group } \\
\text { average) }\end{array}$ & $\begin{array}{l}\text { (job value: below group } \\
\text { average) } \\
94 \% \text { (deviates) }\left(^{*}\right) \\
92 \% \text { (not deviate) }\end{array}$ \\
\hline $\begin{array}{l}\text { Has some } \\
\text { qualifications }\end{array}$ & $4 \%$ & $43 \%$ & $\begin{array}{l}\begin{array}{l}35 \% \\
\text { ties) }\end{array} \\
68 \% \text { (strong ties) }\end{array}$ & $\begin{array}{l}52 \% \text { (below the } \\
\text { average) } \\
73 \% \text { (above the } \\
\text { average) }\end{array}$ & $\begin{array}{l}\text { (job value: above group } \\
\text { average ) } \\
61 \% \text { (deviates) } \\
85 \% \text { (not deviate) }\end{array}$ \\
\hline
\end{tabular}

Values of job higher than 8 are above the average of the young male group which is between the ranges of 1 to 10 . (*) To deviate is when the dummy variable Deviate $N W$ is equal to 1 , which is the case when someone, who has some or all non-employed friends, believes that it is important to have a fulfilling and gratifying job. 
Table 5.A Estimated probabilities after controlling for "individual" factors: Mature Female (age 25-49) Average group probability of being non-working mother (i.e., an at home carer) $=62 \%$

Estimated individual probability of being non-working mother for a mature female who:

\begin{tabular}{|c|c|c|c|c|c|c|}
\hline & \multicolumn{3}{|c|}{ Wants to change into working } & \multicolumn{3}{|c|}{ Does not want to change into working } \\
\hline & $\begin{array}{lr}\text { and places } \\
\text { lower } & \text { than } \\
\text { average } & \\
\text { value } & \text { on } \\
\text { family } & \text { life } \\
(\wedge) & \end{array}$ & $\begin{array}{l}\text { and places } \\
\text { higher than } \\
\text { average } \\
\text { values on } \\
\text { family life }\end{array}$ & $\begin{array}{l}\text { and places a } \\
\text { higher than } \\
\text { average value } \\
\text { on family life, } \\
\text { and has weak or } \\
\text { strong ties with } \\
\text { active friends } \\
(\wedge \wedge)\end{array}$ & $\begin{array}{l}\text { and places } \\
\text { lower than } \\
\text { average } \\
\text { value on } \\
\text { family life }\end{array}$ & $\begin{array}{l}\text { and places a } \\
\text { higher than } \\
\text { average } \\
\text { value on } \\
\text { family life }\end{array}$ & $\begin{array}{l}\text { and places a higher } \\
\text { than average value } \\
\text { on family life, and } \\
\text { has weak or strong } \\
\text { ties with active } \\
\text { friends }\end{array}$ \\
\hline $\begin{array}{l}\text { Does not } \\
\text { have } \\
\text { young } \\
\text { children }\end{array}$ & $31 \%$ & $42 \%$ & $\begin{array}{l}45 \% \text { (weak ties) } \\
24 \% \text { (strong ties) }\end{array}$ & $38 \%$ & $52 \%$ & $\begin{array}{l}54 \%(\text { weak ties }) \\
53 \%(\text { strong ties })\end{array}$ \\
\hline $\begin{array}{l}\text { Has young } \\
\text { children }\end{array}$ & $60 \%$ & $77 \%$ & $\begin{array}{l}79 \%(\text { weak ties }) \\
73 \% \text { (strong ties })\end{array}$ & $69 \%$ & $85 \%$ & $\begin{array}{l}85 \%(\text { weak ties }) \\
81 \%(\text { strong ties })\end{array}$ \\
\hline
\end{tabular}

$\left({ }^{\wedge}\right)$ For values of Value of family life below 25;

$(\wedge \wedge)$ InterACTties : Weak ties $=0$ (absence of ties with active friends); strong ties $=1$ (presence of strong ties with all active friends

\section{Table 5.B Estimated probabilities after controlling for "individual" factors: Mature Male (age 25-49)}

Average group probability of being disabled $=44 \%$

\begin{tabular}{|c|c|c|c|c|c|}
\hline \multicolumn{6}{|c|}{ Estimated individual probability of being disable for a mature male who: } \\
\hline & \multicolumn{3}{|c|}{ Has working limiting disabilities } & \multirow[t]{2}{*}{$\begin{array}{lr}\text { Has not } \\
\text { disabilities }\end{array}$} & working limiting \\
\hline & & $\begin{array}{l}\text { And has a higher than } \\
\text { average degree of } \\
\text { relatedness and places } \\
\text { a higher than average } \\
\text { value on wealth }\left({ }^{*}\right)\end{array}$ & $\begin{array}{l}\text { And has a lower than } \\
\text { average degree of } \\
\text { relatedness, and places a } \\
\text { lower than average value } \\
\text { on wealth }\end{array}$ & & $\begin{array}{l}\text { And has a higher } \\
\text { than average degree } \\
\text { of relatedness, and } \\
\text { places higher than } \\
\text { average value on } \\
\text { wealth }\end{array}$ \\
\hline $\begin{array}{lr}\text { wants to } \\
\text { change his } \\
\text { status into } \\
\text { working }\end{array}$ & $45 \%$ & $36 \%$ & $75 \%$ & $6 \%$ & $3 \%$ \\
\hline $\begin{array}{lr}\text { does r not } \\
\text { want ro } \\
\text { change his } \\
\text { status into } \\
\text { working }\end{array}$ & $86 \%$ & $80 \%$ & $96 \%$ & $22 \%$ & $15 \%$ \\
\hline
\end{tabular}


Table 6. Estimated probabilities after controlling for "individual" factors: Old Male (50-64)

Average group probability of being retired $=50 \%$

Estimated individual probability of being retired for an old male who:

\begin{tabular}{|l|l|l|l|l|}
\hline & \multicolumn{3}{|l|}{ Has working limiting disabilities } & \multicolumn{2}{l|}{ Has not working limiting disabilities } \\
\hline & $\begin{array}{l}\text { and has closest friends } \\
\text { who are all: }\end{array}$ & $\begin{array}{l}\text { and has closest friends } \\
\text { who are all: }\end{array}$ \\
\hline $\begin{array}{l}\text { Has no } \\
\text { qualifications }\end{array}$ & $18 \%$ & $\begin{array}{l}28 \% \text { (inactive) } \\
13 \% \text { (active) }\end{array}$ & $48 \%$ & $81 \%$ (inactive) \\
\hline $\begin{array}{l}\text { Has some } \\
\text { qualifications }\end{array}$ & $40 \%$ & $\begin{array}{l}46 \% \text { (inactive) } \\
27 \% \text { (active) }\end{array}$ & $83 \%$ & $96 \%$ (inactive) \\
\end{tabular}




\section{APPENDIX 1}

List of Variables relevant for the estimates of the Logit and Probit models; $\left({ }^{*}\right)=$ dummy variable

\section{Dependent variables}

At home carers*

Disabled*

Employed*

Students*

Not employed*

Unemployed*

Retired*
1 if inactive (not in the labour force) as a at home carer, 0 otherwise

1 if inactive (not in the labour force) as disabled, 0 otherwise.

1 if active (in the labour force) and employed (full or part time), 0 otherwise (used in the Logit).

1 if inactive (not in the labour force) as student (or in training), 0 otherwise.

1 if inactive or unemployed, 0 otherwise (used in the Logit).

1 if active (in the labour force) but not employed, 0 otherwise.

1 if inactive (not in labour force) as retired, 0 otherwise.

\section{Labour economics Variables (LMV)}

Age16-24*
Age25-49*
Age50-64*
Black or ethnic minority*
Child 0-12
Dad not at work*
Edu: no qualification*
Edu: GCSE*
Edu: A level*
Edu: Higher*
Limiting health condition*
Lone parent*
Mum not at work*
Partner employed*
Responsibility of caring*

Reservation wage

Voluntary work*
1 if aged 16-24, 0 otherwise.

1 if aged 25-49, 0 otherwise

1 if aged 50-64, 0 otherwise.

1 if the respondent is black or minority ethnic, 0 otherwise.

1 if respondent has at least one child aged under 12 or below, 0 otherwise

1 if father was not working when respondent was aged 14,0 otherwise

1 if no educational qualification, 0 otherwise.

1 if GCSE (or equivalent) is the highest educational qualification, 0 otherwise.

1 if A-level (at least one A level or equivalent) is the highest educational qualification, 0 otherwise.

1 if higher than A level educational qualification, 0 otherwise.

1 if respondent has a working limiting health condition, 0 otherwise.

1 if the respondent is a lone parent, 0 otherwise.

1 if mother was not working when respondent was aged 14,0 otherwise.

1 if respondent has an employed partner, 0 otherwise.

1 if the respondent has any caring responsibilities for children, older or disabled people, neighbours, 0 otherwise (independently of labour market status).

Declared reservation hourly pay.

1 if respondent undertakes any voluntary work, 0 otherwise.

Values and behavioural variables (BEV). These variables are derived from the battery of psychological well-being and general health questions of the questionnaire and a larger score corresponds to higher value of the variable.

Agreeable

Confidence

Conscientious

Extravert

Gain in confidence

Gain in optimism
Index variable scaled 0 to 2 about how often respondents attend voluntary work and /or voluntary groups This variable is a proxy for agreeability which is a personality trait that indicates a person's tendency to be compassionate and cooperative rather than suspicious and antagonistic.

Index variable scaled 3 to 15 from the psychological well-being part of the questionnaire about feeling useful, being able to deal with problems and thinking clearly.

Index variable scaled 0-30, about being conscientiousness in "environmental and green" choices. It is a proxy for conscientiousness which is a personality traits that indicates a person's tendency to be organized and dependable, and it shows self-discipline, acting dutifully, aim for achievements and prefer planned rather than spontaneous behavior.

Index variable scaled 0-3, about occasions to meet other people, play sports and attend classes. It is a proxy for for extraversion which is a personality trait that indicates a person's tendency to have positive emotions, surgency, assertiveness, sociability and the tendency to seek stimulation in the company of others, and talkativeness.

Index variable scaled 0-5 higher score equates to more gains in confidence. This variable is derived from questions from the general health questionnaire such as feeling better than usual in playing as useful role, in ability to face problems, gaining confidence, believe in self-worth, and ability in overcoming difficulties.

Index variable scaled 0-5 higher score is more gain in optimism. This variable is derived from questions from 
the general health questionnaire such as feeling better than usual in concentrating, in not losing sleep, in enjoying day to day activities, in not feeling depressed and under strain.

Loss in confidence

Loss in optimism

Optimism and relax

Optimism

Relatedness

Risk

Value of family life

Value of job

Value of wealth
Index variable scaled 0-5 higher score equates to bigger losses in confidence. This variable is derived from the general health questionnaire such as feeling worse than usual in playing as useful role, in ability to face problems, losing confidence, not believe in self-worth, and inability in overcoming difficulties.

Index variable scaled 0-5 higher score is bigger loss gain in optimism. This variable is derived from questions from the general health questionnaire such as feeling worse than usual in concentrating, in losing sleep, in enjoying day to day activities, in feeling depressed and under strain.

Index variable scaled 2-10 from "well-being "questions about have been feeling optimistic about the future often or most of the time and/or having been feeling relaxed.

Index variable scaled 1-5 from "well-being "questions: have been feeling optimistic about the future often or most of the time.

Index variable scaled 1 to 5 about how respondents have felt recently about their connections with others (feeling close to other people).

Index variable scaled 2-20, higher score means willing to take more risk (take in general risks and take risk in trusting strangers).

Index variable to rank the value attributed to family life, scaled 3-30 (Importance of having children, importance of good friends, importance of having partnership). Higher score higher value.

Index variable scaled 1 to10 to rank importance of having a fulfilling job. Higher score higher value.

Index variable scaled 2 to 20 to rank the value attributed to wealth, such as importance of money and importance of owing own home. Higher score higher value.

Satisfaction, well-being and capabilities variables (SatV). These variables are derived from the battery of life satisfaction questions and a larger value corresponds to more satisfaction.

Better off than past*

Capabilities and material opportunities

Less satisfied than in the past

More satisfied than in the past*

Satisfied with job

Satisfied with family life

Satisfied with wealth

Want to change labour market status *

Worse off than in the past *
1 if respondent feels better off in terms of improvement in financial position since last year, 0 otherwise.

Material opportunities other than financial income. Index variable from adding six $(0,1)$ dummies: being owner occupier, having access to internet, having access to a car, having a mobile phone, having a satellite/cable TV, having a land line.

1 if less satisfied, 0 otherwise (taken from life satisfaction index: less satisfied compared to previous year).

1 if more satisfied, 0 otherwise (taken from life satisfaction index: more satisfied compared to previous year).

Index variable scaled 1-14, higher score higher satisfaction with job and amount of leisure time.

Index variable scaled 2 to 21 to rank satisfaction with satisfaction with spouse or partner, social life, use of leisure time.

Index variable scaled 2-14, higher score means higher satisfaction with own wealth (satisfaction with house/flat and satisfaction with income of household).

1 if a non-working respondent has a desire to have a regularly paid job or has actively looked for a job it in the last month, 0 if the respondent has not looked and does not have any interest in finding a full or a part time job.

1 if respondent feels worse off in terms of improvement in financial position since last year, 0 otherwise.

\section{Social influence and social capital variables (SNA).}

High local unemployment

More embedded *

Strength of social ties
Percentage of local unemployment if above $30 \%, 0$ if below.

1 if respondent reported at least two of the following: feel to belong to the neighbourhood or to have seek advice locally; 0 otherwise.

Proportion of respondent's best friends seeing "often" (often is defined as most days or at least once a week). The variable can take values: $0,1 / 3,1 / 2,2 / 3$ and 1 . Higher values indicate stronger ties. 
Proportion of inactive friends Proportion of the three closest friends (network) who are inactive (not employed and not unemployed).

Interaction term variables across personal attitudes and social influence (INTERV). These variables are built as interaction terms by combining some of the above variables

ConformNW*

ConfomrW*

DeviateNW*

DeviateW*

InterACTtie

InterEMPLTie

InterINACTTie

InterNOTEMPLTie
1 if a respondent lacks working aspirations ${ }^{1}$ (i.e., is emotionally detached from the labour market) and has a high percentage of closest friends in non-employment (between $30 \%$ to $100 \%$ are workless), 0 otherwise. The respondent "conforms" to the non-working norm of close friends. The interaction term is the product of two variables: the value of job (when value of job is below or equal to 6), and the proportion of non-working friends (when the proportion of not working friends is above $30 \%$ ).

1 if a respondent has high working aspirations (i.e., is emotionally attached to the labour market) and all closest friends are employment, 0 otherwise. The respondent "conforms" to the working norm of close friends. The interaction term is the product of two variables: the value of job (when value of job is above 6), and the proportion of non working friends (when the proportion of not working friends is zero).

1 if a respondent has high working aspirations (i.e., is emotionally attached to the labour market) and has a high percentage of closest friends in non-employment (between $30 \%$ to $100 \%$ are workless), 0 otherwise. The respondent "deviates" from the non-working norm of close friends. The interaction term is the product of two variables: the value of job (when value of job is above 6), and the proportion of non working friends (when the proportion of not working friends is above $30 \%$ ).

1 if a respondent lacks working aspirations (i.e. is emotionally detached from the labour market) and all closest friends are employment, 0 otherwise. The respondent "deviates" from the working norm of close friends. The interaction term is the product of two variables: the value of job (when value of job is below or equal to 6), and the proportion of non working friends (when the proportion of non-working friends is zero).

Interaction term between strength of ties and labour market status of friends. Stronger ties with close friends who are all active in the labour market (employed or unemployed). The variable can take values: $0,1 / 3 ; 1 / 2$, $2 / 3,1$. Weak ties $=0$ (absence of ties with active friends); strong ties $=1$ (presence of strong ties with all active friends).

Interaction term between strength of ties and labour market status of friends. Stronger ties with close friends who are all employed.). The variable can take values: $0,1 / 3 ; 1 / 2,2 / 3,1$. Weak ties $=0$ (absence of ties with employed friends); strong ties $=1$ (presence of strong ties with all employed friends).

Interaction term between strength of ties and labour market status of friends. Stronger ties with close friends who are all inactive (not employed and not unemployed). ). The variable can take values: $0,1 / 3 ; 1 / 2,2 / 3,1$. Weak ties $=0$ (absence of ties with inactive friends); strong ties $=1$ (presence of strong ties with all inactive friends).

Interaction term between strength of ties and labour market status of friends. Stronger ties with close friends who are all not employed (inactive or unemployed). ). The variable can take values: $0,1 / 3 ; 1 / 2,2 / 3,1$. Weak ties $=0$ (absence of ties with non-working friends); strong ties $=1$ (presence of strong ties with all non-working friends).

\footnotetext{
${ }^{1}$ Working aspirations are measured by attributing low of high importance to a fulfilling job. Low aspirations can be explained in terms of personal motivation or in term of low aspiration and self- esteem. For instance, a woman may genuinely not be interested in working because she prefers and finds it more fulfilling to pursue other activities over working, such as for instance looking after children.
} 


\section{Appendix 2:}

Table 2A: Logistic model. Odds ratio of being non employed relative to being employed

\begin{tabular}{|c|c|c|}
\hline Not Employed versus employed & $\begin{array}{c}\text { Female's odds ratio. } \\
\text { Relative odds of not employed }\end{array}$ & $\begin{array}{c}\text { Male's odds ratios } \\
\text { Relative odds of not employed }\end{array}$ \\
\hline number of observations & 5419 & 4480 \\
\hline Pseudo R square & 0.391 & 0.432 \\
\hline \multicolumn{3}{|c|}{ Labour market Variables } \\
\hline Black or minority ethnic & 1.481 & 2.234 \\
\hline Age16-24 & 5.089 & 10.613 \\
\hline Age50-64 & 2.222 & 2.10 \\
\hline Edu: GCSE & 0.612 & 0.720 \\
\hline Edu: A level & 0.778 & $0.821(\mathrm{NSS})$ \\
\hline Edu: Higher level & 0.578 & 0.651 \\
\hline Partner employed & 0.369 & 0.315 \\
\hline Responsibilities (caring) & 2.539 & 1.506 \\
\hline Health limiting condition & 3.524 & 6.430 \\
\hline Reservation wage & 2.975 & \\
\hline \multicolumn{3}{|c|}{ Behavioural Variables and Values } \\
\hline Optimism & 1.129 & \\
\hline Gain in autonomy & $0.811(*)$ & \\
\hline Loss in autonomy & 1.294 & \\
\hline Gain in confidence & & $1.02(\mathrm{NSS})$ \\
\hline Loss in confidence & & 1.260 \\
\hline Value of family Life & 1.069 & \\
\hline Value of job & 0.718 & 0.788 \\
\hline Extravert & 1.293 & 1.215 \\
\hline Conscientious & $1.000(\mathrm{NSS})$ & $1.000(\mathrm{NSS})$ \\
\hline Risk & 0.966 & \\
\hline \multicolumn{3}{|c|}{ Satisfaction and Capabilities } \\
\hline Better off than past & 0.529 & 0.318 \\
\hline Worse off than past & $1.000(\mathrm{NSS}) 0$ & $1.203(\mathrm{NSS})$ \\
\hline Capabilities and material opport. & 0.719 & 0.636 \\
\hline \multicolumn{3}{|c|}{ Social relations and quality of close network } \\
\hline More embedded & 1.233 & \\
\hline InterNOTEMPLtie & 4.851 & 12.215 \\
\hline InterEMPLtie & 0.532 & 0.245 \\
\hline High local unemployment & 4.441 & 4.544 \\
\hline \multicolumn{3}{|c|}{ Interaction (preferences/beliefs and social norms) } \\
\hline DeviateNW & & 1.448 \\
\hline DeviateW & 0.720 & \\
\hline ConformW & 0.554 & \\
\hline $\begin{array}{l}\text { Notes: The asterisk indicates } \\
\text { significant. In the odds ratios } \\
\text { the odds of being non-employ }\end{array}$ & $\begin{array}{l}\text { o level of significance; }(N S \\
\text { efficient above } 1 \text { indicates t } \\
\text { lative to being employed }\end{array}$ & $\begin{array}{l}\text { dicates }=\text { non statistically } \\
\text { he specific factor increases }\end{array}$ \\
\hline
\end{tabular}




\begin{tabular}{|c|c|c|c|c|c|c|c|}
\hline \multicolumn{8}{|c|}{ Table 2B Predicted Means. Multinomial Probit } \\
\hline \multicolumn{2}{|c|}{ Multinomial PROBIT } & \multicolumn{3}{|c|}{ MALE } & \multicolumn{3}{|c|}{ FEMALE } \\
\hline & & & Predicted & Sample & & Predicted & Sample \\
\hline Age & & Sample & Mean \% & Mean \% & Sample & Mean \% & Mean \% \\
\hline \multirow[t]{4}{*}{ 16-24 } & Unemployed & \multirow[t]{3}{*}{272} & 28.29 & 28.31 & \multirow[t]{4}{*}{342} & 19.09 & 19.01 \\
\hline & Students & & 67.30 & 67.28 & & 54.85 & 54.68 \\
\hline & Disabled & & 4.41 & 4.41 & & 4.15 & 4.09 \\
\hline & At home carers & & & & & 21.91 & 22.22 \\
\hline \multirow[t]{4}{*}{ 25-49 } & Unemployed & \multirow[t]{3}{*}{225} & 51.82 & 51.63 & \multirow[t]{4}{*}{659} & 10.46 & 10.47 \\
\hline & Students & & 4.53 & 4.65 & & 6.53 & 6.37 \\
\hline & Disabled & & 43.65 & 43.72 & & 20.29 & 20.33 \\
\hline & At home carers & & & & & 62.72 & 62.82 \\
\hline & 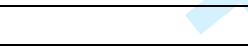 & & & & & & \\
\hline \multirow[t]{4}{*}{$50-64$} & Retired & \multirow[t]{3}{*}{291} & 50.27 & 50.17 & \multirow[t]{4}{*}{631} & 57.74 & 57.62 \\
\hline & Unemployed & & 12.93 & 13.06 & & 3.33 & 3.33 \\
\hline & Disabled & & 36.81 & 36.77 & & 18.22 & 18.25 \\
\hline & At home carers & 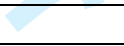 & & & & 20.71 & 20.79 \\
\hline
\end{tabular}




\begin{tabular}{|c|c|c|c|c|c|c|}
\hline \multicolumn{7}{|c|}{$\begin{array}{l}\text { Table 2C Multinomial Probit Estimates MALE } \\
\text { Notes: } Z \text { values in parenthesis; an asterisk }(*) \text { means a significance level of } 10 \%\end{array}$} \\
\hline \multirow{2}{*}{$\begin{array}{l}\text { Probability of inactive status } \\
\text { relative to reference group } \\
\text { (unemployed) }\end{array}$} & \multicolumn{2}{|c|}{$\begin{array}{c}\text { AGE 16-24 } \\
(\text { No. obs }=272)\end{array}$} & \multicolumn{2}{|c|}{$\begin{array}{c}\text { AGE 25-49 } \\
(\text { No. obs }=225)\end{array}$} & \multicolumn{2}{|c|}{$\begin{array}{c}\text { Age 50-65 } \\
(\text { No. obs }=291)\end{array}$} \\
\hline & $\begin{array}{c}\text { Students } \\
\text { relative to } \\
\text { Unemployed }\end{array}$ & $\begin{array}{c}\text { Disabled } \\
\text { relative to } \\
\text { Unemployed }\end{array}$ & $\begin{array}{c}\text { Students } \\
\text { relative to } \\
\text { Unemployed }\end{array}$ & $\begin{array}{c}\text { Disabled } \\
\text { relative to } \\
\text { Unemployed }\end{array}$ & $\begin{array}{c}\text { Retired } \\
\text { relative to } \\
\text { Unemployed }\end{array}$ & $\begin{array}{c}\text { Disabled } \\
\text { relative to } \\
\text { Unemployed }\end{array}$ \\
\hline \multicolumn{7}{|c|}{ Labour market variables } \\
\hline Black, minority ethnic & & & $-0.81(-0.12)$ & $-1.82(-1.66)^{*}$ & $-2.84(-1.71)^{*}$ & $0.95(0.71)$ \\
\hline Edu: No qualification & $-1.47(-3.21)$ & $-1.58(-2.12)$ & & & $-1.16(-2.49)$ & $0.14(0.31)$ \\
\hline Edu: GCSE & & & & & $-1.05(-1.76)^{*}$ & $0.04(0.07)$ \\
\hline Edu: Higher & & & $4.15(2.13)$ & $-0.47(-0.8)$ & & \\
\hline Responsibilities (caring) & & & $-1.67(-1.12)$ & $-0.77(-2.21)$ & & \\
\hline Health limiting condition & & & $0.52(0.4)$ & $2.30(6.06)$ & $0.74(1.61)$ & $2.29(5.29)$ \\
\hline Voluntary work & $1.23(3.52)$ & $1.15(3.06)$ & & & & \\
\hline \multicolumn{7}{|c|}{ Behavioural and values variables } \\
\hline Gain in optimism & & & & & $-0.04(-0.19)$ & $-0.28(-1.4)$ \\
\hline Loss in optimism & & & & & $-0.34(-2.55)$ & $-0.09(-0.76)$ \\
\hline Relatedness & $-0.01(-0.03)$ & $-0.77(-2.55)$ & $1.32(1.14)$ & $-0.50(-2.66)$ & & \\
\hline Conscientious & $0.06(1.81)^{*}$ & $0.07(1.33)$ & & & & \\
\hline Value of job & $-0.21(-2.1)$ & $-0.30(-2)$ & $1.51(1.82)^{*}$ & $-0.06(-0.73)$ & & \\
\hline Value of wealth & & & $-0.44(-2.05)$ & $-0.09(-2.16)$ & & \\
\hline \multicolumn{7}{|c|}{ Satisfaction and Capabilities } \\
\hline More satisfied than past & $0.61(1.72)^{*}$ & $0.74(1.25)$ & $3.34(1.72)^{*}$ & $0.75(1.51)$ & & \\
\hline Less satisfied than past & $-0.83(-3.14)$ & $0.32(0.56)$ & $-2.44(-1.07)$ & $0.29(0.78)$ & & \\
\hline Satisfaction with family life & & & & & $0.17(3.21)$ & $-0.01(-0.05)$ \\
\hline Want to change & $-2.51(-6.66)$ & $-2.28(-4.17)$ & $-4.21(-2.64)$ & $-1.85(-4.97)$ & $-2.46(-5.32)$ & $-1.47(-3.64)$ \\
\hline $\begin{array}{l}\text { Capabilities and material } \\
\text { opportunities }\end{array}$ & & & & & $0.47(3.41)$ & $0.10(0.83)$ \\
\hline \multicolumn{7}{|c|}{ Social relations and close network variables } \\
\hline More embedded & $0.36(1.12)$ & $1.72(2.59)$ & $-4.56(-2.12)$ & $0.13(0.32)$ & & \\
\hline Strength of social ties & & +2 & & & $-1.23(-2.3)$ & $-0.23(-0.49)$ \\
\hline InterINACTtie & & & $5.51(1.65)^{*}$ & $-1.49(-1.63)^{*}$ & & \\
\hline InterACTtie & $-1.22(-2.51)$ & $-0.69(-0.83)$ & 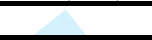 & & & \\
\hline High local unemployment $(>30)$ & & & & & $-2.97(-2.68)$ & $-1.75(-1.62)$ \\
\hline Proportion of inactive close friends & & & & & $2.34(3.33)$ & $1.18(1.8)^{*}$ \\
\hline \multicolumn{7}{|c|}{ Interaction (preferences/beliefs and social norms) variables } \\
\hline DeviateNW & $0.99(2.45)$ & $-0.14(-0.22)$ & & & $-0.17(-0.37)$ & $-0.77(-1.82)^{*}$ \\
\hline DeviateW & & & $-8.44(-0.01)$ & $-1.04(-1.93)$ & & \\
\hline$\overline{\text { Constant }}$ & $2.27(2.03)$ & $2.66(1.48)$ & $-12.79(-1.2)$ & $2.72(2.66)$ & $-1.40(-1.3)$ & $0.41(0.43)$ \\
\hline
\end{tabular}




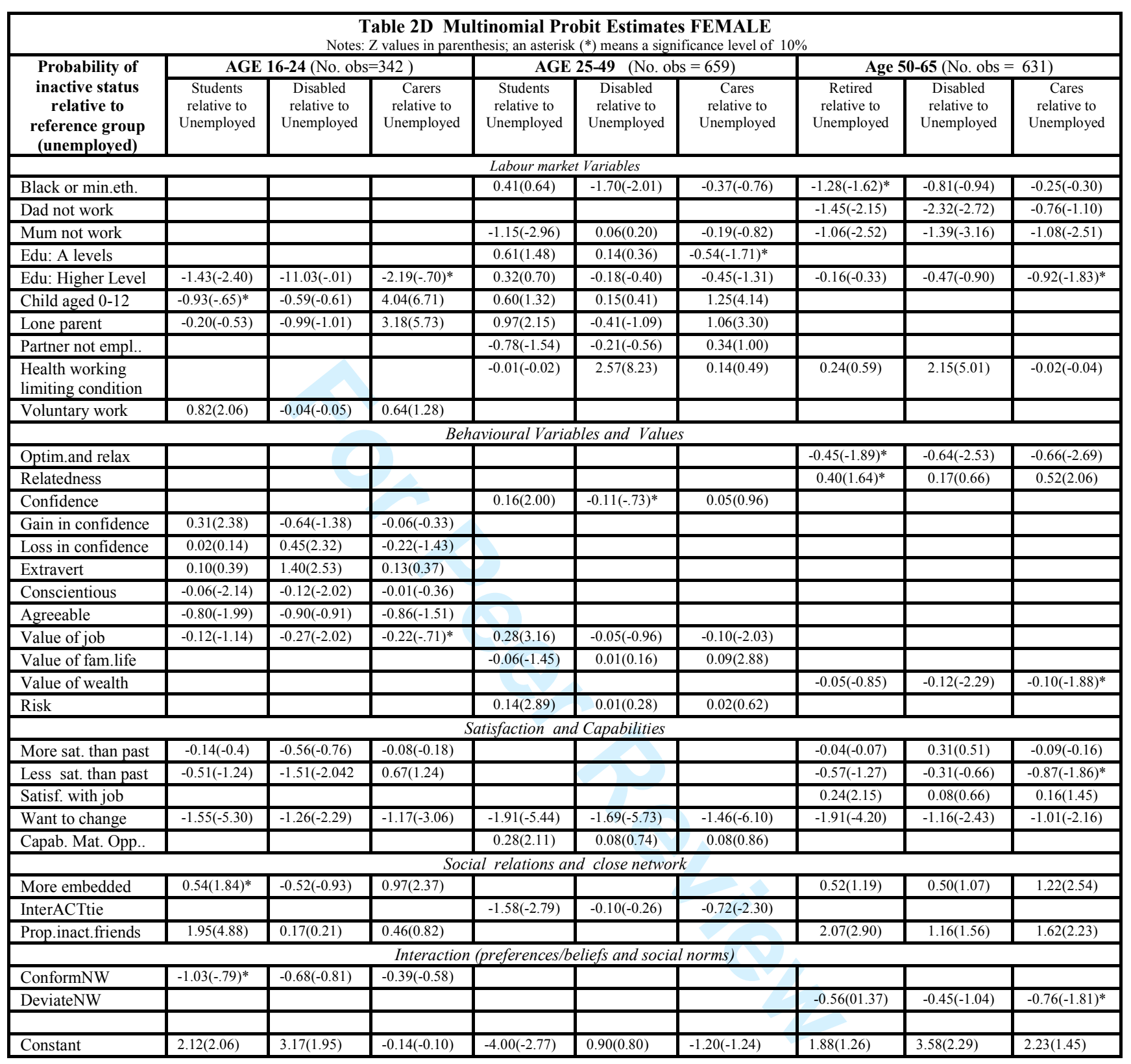

